\title{
Gâî Yorum/Makâsıd Açısından Hz. Ömer'in Sevad Arazisi İle İlgili Uygulamasına Yönelik Bir Değerlendirme*
}

\author{
Prof. Dr. Nasi ASLAN ${ }^{\star * *}$
}

Atıf / @-- Aslan, N. (2018). Gâî Yorum/Makâsıd Açısından Hz. Ömer'in Sevad Arazisi ile İlgili Uygulamasına Yönelik Bir Değerlendirme, Çukurova Üniversitesi Illahiyat Fakültesi Dergisi, 18 (2), 691-717.

Öz- Bilindiği üzere, hukukta yorumla ilgili "lafzi" ve "gaî" olmak üzere iki ana ekol öne çıkar. Maalesef fıkıh usulündeki lafzî mebhas içerisinde yer alan delalet şekilleri ve kıyas bahislerinde -bazı istisnaları dışarıda bırakacak olursak- lafzîliteral yorumun dışına pek çıkılamamıştır. Bu da nasların arkasında maksûd olan hikmet ve gayenin göz ardı edilmesinden kaynaklanmaktadır.

Oysa Yüce Allah yaratılışı belli bir hikmete mebni gerçekleştirdiği gibi koyduğu hükümlerde de belli bir gayeyi hedeflemiştir. Bu çerçevede Kur'an ve sünnette yer alan hükümlerde kulların hem ahirete hem de bu dünyaya dönük maslahatları gözetilmiştir. Buna göre dini literatürde makâsıd-ı şeri'a olarak bilinen dinin korumayı hedeflediği beş esas "canın korunması, malın korunması, neslin/nesebin korunması, dinin korunması ve aklın korunması" şeklinde formüle edilen "tümel gayeleri" içerir. Bu beş esas bir yönüyle Şâri'in hükümlerde gözettiği genel amacı teşkil ederken, bir yönüyle de insanların umumi maslahatlarını ihtiva etmektedir. Diğer taraftan Şârînin naslarda yer alan her bir hükümde gözettiği özel gayeler de vardır ki o da söz konusu nasta gözetilen tikel gayeleri oluşturur. Aslında bu gaye belki de o nassın sevk olunuşu ile ilgili güdülen özel amacı teşkil eder. Sonuçta ilgili nassın bu özel gaye ekseninde tümel gayelerle birlikte yorumlanması gerekir.

Nasların sınırlı olayların sınırsız olduğu düşünüldüğünde literal yorumun ihtiyacı karşılamayacağı bir gerçektir. Bu nedenle Müslümanların karşılaştığı yeni meselelerde vahiyle ortaya çıkan bu yeni hadiseler arasında sağlıklı bir bağ kurulabilmesi Şârînin gözettiği gayelerin dikkate alınmasıyla mümkündür.

Şâriin maksûdu olan gâyelere bir şekilde vakıf olunduktan sonra naslar da bu gayelere mütenasip bir şekilde yorumlanabilir. Nitekim Hz. Ömer'in bazı uygulamaları bunun en güzel örneklerini teşkil eder. Onun fethedilen Sevad arazisi/Irak toprakları ile ilgili uygulaması ise gâî yorumun en özgün

\footnotetext{
* Cumhuriyet Üniversitesi İlahiyat Fakültesi tarafından 2-3 Kasım 2017 yılında düzenlen Uluslararası Hz. Ömer Sempozyumu'nda sunulan bildirinin geliştirilmiş halidir.

** Bu çalışma, Ç.Ü. Araştırma Fonu Saymanlığınca (SBA-2018-10808) desteklenmiştir.

*** Çukurova Üniversitesi İlahiyat Fakültesi İslam Hukuku Anabilim Dalı,

e-posta: nasiaslan@cu.edu.tr, ORCID: 0000-0002-0871-5102
} 
örneklerinden biridir. Çünkü Irak topraklarının tamamına yakını Müslümanlar tarafından kılıç/savaş yoluyla elde edilmiştir. Bu durum Enfal sûresinin 41. Ayeti ve $\mathrm{Hz}$. Peygamberin, Hayber topraklarını taksim etmesi ile ilgili uygulaması dikkate alındığında, Sevad topraklarının da taksim edilmesi sonucunu doğuruyordu. Çünkü konuyla ilgili nasların zahiri de bunu gerektirmekteydi. Oysa Hz. Ömer bu araziyi taksim etmeyerek eski sahiplerinin elinde bırakıp, bu araziden haraç vergisi almayı ve bu şekilde elde edilen geliri Müslümanların kamu yararına harcamayı daha uygun gördü. Bu husus sahabe arasında uzun süren tartışmalara neden oldu. İşte bu araştırmada Hz. Ömer'in söz konusu tasarrufunda ileri sürdüğü gerekçeler -ki mutat uygulamanın devam etmesi halinde yakın ve uzun vadede doğabilecek olumsuz sonuçların da dikkate alınması gayesi- bütün yönleriyle tartışılmaktadır. Hz. Ömer'in bu uygulamasının İslam Hukuku alanındaki tezahürleri ise ayrıca irdelenecektir.

Anahtar sözcükler- Gâî yorum, Hz. Ömer, Hikmet, Sevad Toprakları, Ganimet.

\section{$\S \S \S$}

\section{Giriş}

Şârî’in dinî hükümleri koyarken gözettiği ana gayeleri nasların yorumu ve anlaşılmasında merkeze alan anlayış başlangıçta makâsıdü'ş-şeria, hikmetüt'teşrî gibi terimlerle isimlendirilse de günümüzde kısaca "makâsıd", "maslahat" ve "hikmet" şeklinde ifade edilmekte olup bununla da genelde murad olunan gâî yorumdur.

Cüveynî (ö. 478/1085) ve Gazzâlî (ö. 505/1111) ile başlayan gâî yorum tartışmaları İzz b. Abdisselâm (ö. 660/1262) ve Şihabeddîn el-Karâfî (ö. 684/1285) ile bir esasa dönüşmüş, İmam Şâtıbî (ö. 790/1388) de el-Muvâfakât adlı eseriyle gâî yorumun ilkelerini belirleyerek bu nazariyeyi sistematik hale getirmiştir.

Hz. Ömer gaî yorum esasını her ne kadar teorik düzlemde tartışmamış olsa da onun pratik uygulamaları gâî yorumun en özgün örneklerini oluşturur. Nitekim onun sevâd toprakları ile ilgili tasarrufu da bunun en önemli örneklerinden biridir.

Sevâd, genel manada bugünkü Irak topraklarına tekabül etmektedir. Arap coğrafyacıları Dicle ile Fırat nehirleri arasındaki bölgeyi iki kısma ayırırlar güney kısmına Irak veya sevad ismini verirler. Kuzey kısmına da el-Cezîre 
derler. Bu bölgeye sevad denilmesi şu şekilde açıklanır. Arapların İslam fetihleri sırasında çölün sarı kumları arasından çıkıp Fırat-Dicle havzasındaki ekili ağaçılık ve koyu yeşil alanı kapsayan kara toprakları uzaktan gördüklerinde buraya gece gibi "siyah" anlamına gelen sevâd dedikleri kaydedilmektedir. ${ }^{1}$

Sevâd fethi için ilk akınlar Hz. Ebû Bekir döneminde başladı. Bazı yerler barış yoluyla fethedildi. Halid b. Velid komutasında başlayan düzenli seferler Hz. Ömer döneminde Ebû Ubeyde es-Sekafî ile devam etti. Köprü savaşıyla Müslümanların yenilgiye uğraması neticesi $\mathrm{Hz}$. Ömer Cerîr b. Abdullah elBecelî̀yi kabilesi ile birlikte sevâd bölgesine gönderdi. Arkasından diğer kabileler de Sad b. Ebî Vakkas'ın komutasında birleşerek Kâdisiye savaşında Sâsânî ordusunu mağlup etti (15/636) ve bölgenin önemli bir kısmı ele geçirildi. 642 yılında yapılan Nihavend savaşıyla Sevâd'ın fethi tamamlandı. ${ }^{2}$ Daha sonra $\mathrm{Hz}$. Ömer'in emriyle bölgenin güneyinde Basra ve Kûfe şehirlerinin kurulduğu bilinmektedir.

Hz. Ömer fetihleri yönetip yönlendirmesi, ortaya çıkan problemlerin çözümü, esirler ve gayr-i müslimler hakkındaki kararları, yeni şehirlerin kurulması ve fethi gerçekleştiren askerlerin çok geniş coğrafyaya yerleştirilmesi vs. birçok konuda ilk uygulamaları (evâil) gerçekleştirmiştir. Nitekim onun döneminde fetihler sonucu ele geçirilen ganimetlerde büyük artış oldu. $\mathrm{Hz}$. Ömer, müslümanlarla gayri müslimlere ait yeni ortaya çıkan çeşitli problemleri ve intiyaçları görerek bunların çözümüne ilişkin düzenlemelere teşebbüs etti. Bu düzenlemelere kazanılan ganimetlerle İslâm'ın eline geçen bu çok büyük coğrafyada yaşayan başka din mensupları ve bunların sahip oldukları toprakları ele alarak başladı. ${ }^{3}$ Onun genelde ganimetlerin dağıtılması konusundaki politikası, özelde sevâd arazisi ile ilgili tasarrufu, hikmet eksenli uzun vadeye dayalı gâî yorumun ilk örnekleridir denilebilir. Nitekim araştırma konusu, bu örnek üzerinde temerküz etmekte olup burada gâî yorum/makâsıda dair bu

\footnotetext{
${ }^{1}$ Fayda, Mustafa, Hz. Ömer Zamanında Gayr-ı Müslimler, Marmara Üniversitesi Yayınları, İstanbul 1989, s. 42; Demirci, Mustafa, "Sevâd" DiA, İstanbul 2009, XXXVI, 576.

2 Demirci, "Sevâd" Di̇, XXXVI, 577.

${ }^{3}$ Fayda, Mustafa, "Hz. Ömer" DIA, İstanbul 2007, XXIV, 46,48.
} 
örnekten hareketle pratiğe ilişkin güncel meselelere bu açıdan ışık tutulması amaçlanmaktadır.

Sevâdın fethinden sonra askerlerin Sa'd b. Ebî Vakkâs'tan bu zengin toprakların kendilerine ganimet olarak dağıtılmasını istemeleri uzun süren tartışmaya neden oldu. Hz. Ömer, Kâdisiye savaşına katılan Becîle kabîlesine fetih gerçekleştiği takdirde Sevâd topraklarının dörtte birini vermeyi vaad etmiş ve sonra sözünü de tutmuştu. Basra çevresinde barış yoluyla elde edilen kalelere ait bazı araziler hariç sevâd'ın tamamına yakını savaşla fethedildiğinden mülkiyetin ümmete ait olduğu sonucuna varılıp, daha önce Becîle kabilesine verilen topraklar da geri alınarak eski sahiplerine iade edildi. ${ }^{4}$

Hz. Ömer Nihavend savaşından bir yıl sonra (22/643) sevâd topraklarının alanının tespiti, burada çalışan nüfusun belirlenmesi ve vergi miktarlarının tayini için Dicle'nin batı tarafına Osman b. Huneyf'i, doğu tarafına ise Huzeyfe b. Yeman'ı gönderdi. Onlar tarafından bölgede cizye vermeye muktedir 500.000 erkek çiftçinin bulunduğu, Medâin ile Celûla arasında 170.000 kişinin yaşadığı tespit edilmiştir. Bunun neticesinde ilk yıl 100 milyon ikinci yıl 128 milyon dirhem vergi toplanmıştır. ${ }^{5}$

\section{Ganimetlerle İlgili Düzenleyici Hükümler}

Ganimetlerin dağıtılması hususu İslam öncesi cahiliye döneminden beri söz konusu olmuştur. Zira bu dönemlerde Arap yarımadasındaki mevcut uygulamaya göre savaşı kazanan ordunun komutanı, ganimetin dörtte birini kendisine ayırır, bölünmesi mümkün olmayan mallar da ona ait olurdu. ${ }^{6}$ Ancak Hz. Peygamber'in Medine'ye hicretinden sonra cahiliye döneminde hüküm süren bu ve benzeri uygulamaları kaldırılmış; Enfal sûresinin 69. Ayetinde de

\footnotetext{
${ }^{4}$ Belâzurî, Ahmed b.Yahya, Fütûhu'l-Büldân, (çev. M. Fayda) Siyer Yayınları, İstanbul 2013, s. 302305; Demirci, "Sevâd" DiA, XXXVI, 577.

${ }^{5}$ Belâzurî, Fütûhu'l-Büldân, s. 306-307; Fayda, Hz. Ömer Zamanında Gayr-ı Müslimler, s. 43; Demirci, "Sevâd" DIA, XXXVI, 577.

${ }^{6}$ Erkal, Mehmet, “Ganîmet” DiA, İstanbul 1996, XIII. 351.
} 
beyan olunduğu üzere ganimetin kendisine ve ümmetine helal kılındığını bildirmiştir. $^{7}$

Hicretin 2. Yılında yapılan Bedir savaşına kadar ganimet konusunu düzenleyen herhangi bir ayet nazil olmamıştır. Ancak Bedir savaşından sonra büyük miktarda esir ve mal ele geçirilip Müslümanlar arasında anlaşmazlık çıkınca bunun üzerine 8. Enfal 1. ayet nazil olmuştur. Bu ayette ganimetlerin Allah'a ve Resulüne ait olduğu belirtilmiş, $\mathrm{Hz}$. Peygamber de bu ganimetleri savaşa katılan mücahitler arasında eşit olarak taksim etmiştir. Aynı surenin, "Bilin ki, savaş ganimeti olarak elde ettiğiniz şeylerin beşte biri Allah'a, Peygamber'e, onun yakınlarına, yetimlere, yoksullara ve yolculara aittir. Eğer Allah'a, hak ile batılın birbirinden ayrıldığı gün, (yani) iki ordunun(Bedir'de) karşılaştığı gün kulumuza indirdiklerimize inansaydınız (bunu böyle bilin). Allah her şeye hakkıyla gücü yetendir." mealindeki Enfâl sûresinin 41. Ayeti nazil olunca ganimetlerle ilgili ayrıntılı hükümler belli olmuştur. Bu ayetin hükümleri ilk kez Benî Kaynuka Yahudilerinden alınan ganimetlere uygulanmıştır. Daha sonra Hz. Peygamber savaş yolu ile elde edilen Benî Kureyza, Hayber ve Vadi'l-Kura ganimetlerini bu ayette beyan edilen hüküm üzere dağıtmış, ancak Hayber'in bir bölümü ve Vadi'l-Kura arazisini Yahudilere yarıcılık yoluyla işletmeye verilmiştir ${ }^{8}$. Fakat bu uygulama fazla uzun sürmemiş, Hz. Ömer'in hilafeti döneminde Hayber Yahudileri bu topraklardan çıkarılarak araziler tekrar hisse sahiplerine dağıtılmıştır. Beni Nadir ve fedek arazisi barış yoluyla ele geçirildiğinden Haşr sûresinin 6-9. ayetlerinin (fey) hükmü uygulanarak $\mathrm{Hz}$. Peygamber'e ait kabul edilmiş, o da elde edilen gelirleri yolcuların, Haşimoğullarının fakirlerinin intiyaçları ve devletin savunma giderleri için harcamıştır. ${ }^{9}$ Burada Hayber'in savaş yoluyla mı ya da barış yoluyla mı, yahut bir kısmının savaş yoluyla bir kısmının da barışla mı fethedildiği konusunda

\footnotetext{
${ }^{7}$ Buhârî, Muhammed b. İsmâil, Sahîhu'l-Buhârî, Dâru İbn Kesîr, Beyrut 1993, Humus, 8; Müslim, Müslim b. el-Haccâc, Sahîhu Müslim, Dâru İhyâi'l-Kütübi'l-Arabiyye, Kahire 1991, Mesâcid 3,5; Tirmizî, Muhammed b. İsa, Sünen, Matba'ati Mustafa el-Bâbî, 1962-1977, Siyer 5.

8 Fayda, Hz. Ömer Zamanında Gayr-ı Müslimler, s. 43; Erkal, "Ganîmet" DIA, XIII, 352

${ }^{9}$ Erkal, "Ganîmet" DIA, XIII. 352.
} 
farklı rivayetler mevcuttur. ${ }^{10}$ Bu farklı rivayetlere bağlı olarak Hz. Peygamber'in bu toprakların tamamını taksim ettiği; bir kısmını taksim edip bir kısmını yarıcılık usulü ile sahiplerinde bıraktığı şeklinde uygulama ile ilgili farklı rivayetler de mevcuttur. Bu zikrolunanlardan Hz. Peygamber'in Hayber'in tamamını taksim etmeyip bir kısmını taksim ettiği görüşü öne çıkmaktadır. Sonuçta Hz. Ömer'in Sevad arazisinin taksimine muhalefet eden sahabileri bu argümanla ikna etmeye çalışmış olması da mümkündür. ${ }^{11}$

Konuyla ilgili Enfal suresi 41. ayetinin getirdiği hükümler ve $\mathrm{Hz}$. Peygamber'in uygulaması ortadayken Hz. Ömer, hikmeti esas alan gâî bir yorumla, savaş yoluyla ('anveten) elde edilen toprakları esas sahipleri olan yerli halka haraç karşılığında bırakmış ve onlardan cizye alınmasını kararlaştırmıştır. Yani ganimet statüsünde bulunan ve Enfal 41. ayetinde belirtildiği üzere taksim edilmesi gereken topraklara "fey" hükmünü uygulamış ve bu yorumunu da 59. Haşr 7-11. ayetleriyle desteklemiştir.

\section{Hz. Ömer'in Fethedilen Sevad Arazisini Dağıtmaması Hususunda}

\section{Öne Sürdüğü Gâî Gerekçeleri}

Her şeyden önce Şâri'in vaz ettiği hükümlerde gözettiği gâî maksatların olduğunu yukarıda belirtmiştik. İşte bu gayeler çeşitli şekillerde bilinebilir, buna dair şu ölçütler esas alınabilir.

a-) Konuyla ilgili doğrudan ve açık, bir emir veya yasağın olması. Çünkü emir, yapmayı (fiil) gerektirdiğinden dolayı emir olur. Böyle bir durumda fiilin yapılması Şâri'in maksadıdır. Yapmamak konusundaki yasak da böyledir.

b-) Emir ve yasakların illetlerini dikkate alınması. Neslin devamına dönük fayda için nikâh, akit konusu maldan faydalanmaya dönük maslahat için alımsatım gibi.

c-) Şâri'in norm koymasında aslî ve tâlî (tabî) gayeleri bulunup bunların ortaya konulması. Bu gayelerin mansûsu (Kur'an ve sünnetteki normların lafızlarıyla ifade edilen mana ve gayeler) vardır, işaret edileni vardır, (yani

\footnotetext{
10 Şelebî Hayber'in tamamın savaş yoluyla fethedildiği görüşünün daha isabetli olduğunu belirtir. Bkz. Şelebî, Muhammed Mustafa, Ta'lîlü'l-Âhkâm, Beyrut 1981, s. 50.

${ }^{11}$ Şelebî, Ta'lîü'l-Âhkâm, s. 50.
} 
naslardan istidlal ile çıkarılanı vardır Böylece nasla belirtilmeyenlerin de şâriin maksudu olabileceği sonucu çıkar. ${ }^{12}$

Şâriin maksûdu olan gâyeler çeşitli yollarla bilindikten sonra naslar da bu gayelere mütenasip bir şekilde yorumlanabilir. Bu durum $\mathrm{Hz}$. Ömer'in birçok uygulamasında daha açık şekilde görülür. Nitekim Irak, Hz. Ömer devrinde Müslümanlar tarafından kılıçla fethedildikten sonra o, bu araziyi eski sahiplerinin elinde bırakıp, bu araziden haraç almayı ve bu şekilde elde edilen geliri Müslümanların kamu yararına harcamayı daha uygun gördü. Bu konuda Haşr suresinin 6-10. ayetlerini temel dayanak alarak söz konusu ayetleri daha farklı yorumlamıştı. Buna göre ganimetlerin dağıtılmasını konu alan Enfal suresinin 41. âyeti, Haşr suresinin 6-10. âyetleri ile tahsis edilmiştir. Nitekim Enfal suresinin 41. Âyeti ve Haşr sûresinin ilgili âyetleri ganîmetlerin dağıtılması ile ilgilidir.

Sahabenin büyük çoğunluğu ise menkul malların savaş gazileri arasında dağıtıldığı gibi bu arazinin de taksim edilmesini istemekte, bu konuda $\mathrm{Hz}$. Peygamberin, Hayber topraklarını taksim etmiş olması ile Enfal suresinin 41. âyetini delil olarak gösteriyorlardı. Ayrıca onlara göre Haşr sûresinin ilgili âyetleri ile Enfal suresinin 41. âyeti arasında bir ilgi de yok ki tahsisten söz edilebilsin. Enfal suresinin 41. âyeti kılıç zoruyla, Haşr suresi 6-10. âyetleri ise sulh yoluyla elde edilen "fey" 13 hakkında idi.

Bu konuyla ilgili bir rivayete göre Irak fethedildiği zaman askeri birliklerin komutanı Sa'd b. Ebi Vakkas Hz. Ömer'in çözümüne mevzu olan bu sorunu Hz. Ömer'e bir mektup yazarak iletmiş, Hz. Ömer ise cevaben şöyle demiştir: "Mektubun bana ulaştı. Anlattığına göre insanlar/gaziler senden ganimetleri ve Allah'ın fey olarak insan ettiği malları kendilerine taksim etmeni istemişler. Bu mektubum sana gelince bu mesele hakkında iyice düşün. Mal, hayvan ve eşya olarak sana getirilen ganimetleri topla. Onları, Müslümanlardan orada hazır

\footnotetext{
12 Şâtıbî, Ebû İshak, el-Muvâfakât, Dâru'l-Fikr, y.y., t.y., II, 273-278 ; İbn Âşûr, Muhammed Tâhir, İslam Hukuk Felsefesi, (çev. Mehmet Erdoğan; Vecdi Akyüz) Rağbet Yayınları, İstanbul 2006, s. 38,39.

${ }^{13}$ Fey': savaşsız elde edilen ganimetler ve mallar. Ayrıca haraç, cizye, ticari mal vergisi gibi gelirleri de fey kapsamında değerlendirenler var. Bkz. Fayda, Mustafa, "Fey" , DIA, İstanbul 1995, XII, 511513.
} 
bulunanlara bölüştür. Arazi ve nehirleri elinde tutan eski sahiplerine (yerli halka) bırak ki bunlar tüm Müslümanların gelirlerine atiyye olarak dâhil olsun. Şayet sen bu arazileri gazilere taksim edersen, gelecek nesillere hiçbir şey kalmaz. ${ }^{14}$

Bunu teyit eder nitelikte konuyla ilgili diğer bir rivayete göre $\mathrm{Hz}$. Ömer meseleyi önce muhacirlerle müzakere etmiş ancak görüş ayrılığına düşülmüş, bu sırada Abdurrahman b. Avf, toprakların taksim edilmesi gerektiği fikrini savunmuş ve itiraz etmiş. Hz. Ömer ona "Ben böyle düşünmüyorum çünkü benden sonra artık geniş toprakları içeren büyük fetihler gerçekleşmeyecek. Irak ve Şam arazilerini taksim ettiğimde buralarda bulunan ve bulunmayan dul yetim ve muhtaç durumda bulunan gelecek nesillerin ihtiyaçları nereden karşılanacak?" demiş. Bunun üzerine muhacirlerden bazıları muhalefette üsteleyerek "Bizim kılıçlarımızla savaşarak aldığımız bu toprakları ortada bulunmayan bir topluluk yani henüz doğmamış torunların torunları durumundaki şahid olmadığımız kişiler için mi alıkoyacaksın?" diye görüşlerinde ısrarcı olmuşlardı. Tartışma uzayınca Ensar ile de istişare edilmesi istendi Bunun üzerine Hz. Ömer, Ensar'ın ileri gelenlerinden (eşrafından) on kişi çağırmış ve bu meseleyle ilgili görüşünü onlara şöyle aktarmıştır: "Kuşkusuz ben de sizin gibi bir insanım. Siz bugün hak ve hakikat olanı ikrar edersiniz. Bana kiminiz muhalefet, kiminiz de muvafakat etti. Ben sizin, nefsi arzularıma tabi olmanızı istemiyorum. Kaldı ki elinizde hakkı beyan eden bir kitap var. Allah'a yemin ederim ki ne söylüyorsam, emin olun ki onunla ancak hakkı murad ediyorum. Benim kendilerine zulmettiğimi (haklarını gasp ettiğimi) ileri süren insanların sözlerini işittiniz. Ben zulmün sırtına binmekten Allah'a sığınırım. Eğer ben onlara ait olan bir hakkı gasp edip başkalarına vermiş olsaydım, gerçekten zulmetmiş olurdum. Lakin gördüm ki Kisra'nın memleketinden sonra içinde ganimetler bulunan fethedilecek bir yer kalmadı. Allah onların mallarını, topraklarını ve haklarını bize ganimet olarak insan etti. Ganimet olarak elde edilen malları hak sahiplerine taksim ettim. Beşte birini ayırıp mahalline sarf ettim. Ben şu anda onun taksimatıyla meşgulüm. Bundan sonra, savaşanlarla

14 Ebû Yusuf, Kitabu'l-Harâc, Dâru'l-Marife, Beyrut, t,y. s. 28-29; Belâzurî, Fütûhu'l-Büldân, s. 302. 
diğerlerinin ve gelecek nesillerin teşkil ettiği Müslümanlar için fey olmak üzere fethedilen toprakları asıl sahiplerinin elinde bırakmayı, bu topraklara haraç vergisi koymayı, sahiplerine de bir cizye tayin etmeyi uygun gördüm. İşte şu kaleleri görüyorsunuz. Şam, Cezire, Kufe, Basra ve Mısır gibi şu büyük beldeleri görüyorsunuz. Onları sürekli koruyacak insanlara ihtiyaç var. Aksi halde ehli küfür bu beldelere tekrar döner. Onların askerlerle korunması ve o askerlere gelir sağlanması gereklidir. Hal böyleyken arazi ve ırmaklar şu an ki işleyicileriyle birlikte taksim edildiği takdirde askerlerin giderleri nerden karşılanacak?"

Halife Hz. Ömer'in bu ikna edici sözlerinden sonra orada bulunan ensar duydukları karşısında ikna olmuşlar ve "Görüş, senin görüşündür. Mesele açıklığa kavuştu. Düşündüklerin ve söylediklerin ne kadar da güzel!" diyerek ona hak vermişlerdir. ${ }^{15}$

Sevad arazileriyle ilgili başka bir rivayette Hz. Ali'nin Hz. Ömer'e “Orayı (vergi karşılığında) eski sahiplerinin elinde bırak ki orası Müslümanlar için faydalı bir kaynak olsun." şeklindeki tavsiyesine uyarak toprakları taksim etmeyip yerli halkın elinde bırakmaya karar verdiği nakledilmiştir. ${ }^{16}$

Sevad (Irak) toprakları hakkındaki tartışmalarda Hz. Peygamber'in müezzini Bilal'in de muhaliflerin başını çektiği kaydedilmektedir. Söz konusu münakaşalar şiddetle devam ettiği sırada Bilal b. Rebah ve arkadaşları, Hz. Ömer'den Irak ve Şam'dan Allah'ın kendilerine insan ettiği "fey”lerin taksim edilmesini isteyerek şöyle derler: "Askerin elde ettiği ganimetlerin taksim edildiği gibi, arazileri de fatihler arasında paylaştır." Hz. Ömer'in bu talebi kabul etmemesi üzerine, "Biz burayı savaş yoluyla güç kullanarak fethettik." diyerek itiraz ederler. Onların bu itirazlarına Hz. Ömer, " Allah sizden sonra gelecek olanlara bu feye ortak etti. Eğer ben size bu toprakları bölüştürürsem sizden sonra gelecek olanlara bir şey kalmaz. Fakat taksim edilmez de kalırsa, kanı

\footnotetext{
${ }^{15}$ Ebû Yusuf, Kitabu'l-Harâc, s. 26-27; bkz. Şelebî, Ta'lî̈lül-Âhkâm, s. 52.

${ }^{16}$ Ebû Yusuf, Kitabu'l-Harâc, s. 39; Belâzûrî, Fütûhu'l-büldân, s. 303; Şelebî, Ta'lîlü'l-Âhkâm, s. 56; Fayda, Hz. Ömer Zamanında Gayr-ı Müslimler, s. 9.
} 
yüzünde olan (yani savaşa katılmamış ve yara almamış) San'a da ki çobana bile bu "fey"den ayrılacak nasibi mutlaka ulaşır. ${ }^{17}$

Rivayete göre fethi gerçekleştiren komutanlardan Ebû Ubeyde, $\mathrm{Hz}$. Ömer'e fethedilen toprakların durumu ve nasıl uygulamalarda bulunacaklarına dair bir mektup yazdı. Mektubunda Allah'ın Müslümanlara insan ettiği ganimetleri, zimmilerle yapılan sulh şartlarını, elde edilen ganimetlerin, halkıyla birlikte şehirlerin, işleyici ve sahipleriyle beraber arazi, bağ ve bahçelerin kendilerine taksim edilmesi konularındaki Müslümanların isteklerini ve düşüncelerini Hz. Ömer'e iletti. Hz. Ömer ise Ebu Ubeyde'nin mektubuna şöyle cevap verdi:

"Ben Allah'ın sana bahşettiği ganimetleri, şehir ve kasaba halklarıyla akdettiğin sulhnameleri inceledim. Bu konuları Resulullah'ın ashabıyla istişare etim. Herkes bu konuyla ilgili görüşünü bildirdi. Benim görüşüm Allah'ın kitabına dayanmaktadır." dedikten sonra mektubuna "Fey" hükümlerini belirleyen 59 . Haşr 6-8. ayetlerini kaydederek burada belirtilenlerin "ilk muhacirler" olduğunu söyledi. Ardından aynı surenin 9. ayetini de yazarak burada bahsedilenlerin de "Ensar" olduğunu ifade ettikten sonra mektubuna şöyle devam etti. "Allah, feyle ilgili ayetlerin sonunda, "Onlardan (Allah'ın lütfunu ve rızasını talep eden ve yine Allah'a ve elçisinin davasına yardım eden ilk nesil Müslümanlardan) sonra gelenler (Haşr 59/10)" demektedir. "Sonraki nesillerden maksat, Âdem'in beyaz, siyah ve kırmızı çocuklarıdır. Allah, işte bu sonraki nesilleri de bu fey'e ortak etmiştir. Allah'ın sana fethini müyesser kıldığı memleketlerin fey'ini, sahiplerinin elinde bırak. Onlara mali güçleri nispetinde cizye koy ve bu cizyeleri Müslümanlar arasında taksim et. Toprağın imarını onlar(yerli halk) yapsın. Çünkü onlar bu işi daha iyi bilirler ve ziraat işlerine de daha yatkındırlar... Eğer biz o toprakları üzerinde yaşayan insanlarla beraber Müslümanlara taksim edersek/ganimet olarak dağıtırsak, bizden sonraki Müslüman nesillere bir şey kalmaz. Allah'a yemin ederim ki bu topraklar sahipleriyle birlikte Müslümanlara taksim edilirse, gelecek çağlardaki Müslümanlar ve zimmiler konuşacak bir insan dahi bulmadıkları gibi, alın teri kazançlarından da faydalanamazlar.

\footnotetext{
${ }^{17}$ Ebû Yusuf, Kitabu'l-Harâc, s. 25.
} 
Ayrıca topraklarıyla birlikte ganimet hükmüne tabi kılınan bu insanlarsa, Müslümanlar sağ oldukları müddetçe sömürülürler. Neticede bizden sonra gelecek olan çocuklarımız, onların çocuklarını sömürmeye ve onları köle olarak kullanmaya devam ederler. Böylece onlar İslam dini hâkim olduğu müddetçe Müslümanların kölesi olurlar. $\mathrm{Bu}$ durum da onların Müslümanlıktan soğumalarına neden olur. ${ }^{18}$

Aynı doğrultuda başka bir rivayette ise $\mathrm{Hz}$. Ömer Sevad topraklarını gelecek nesilleri düşünerek eski sahiplerinde bıraktı; buranın halkını da zimmî yaptı. Onlardan cizye, topraklarından da haraç alındı. Buna göre onlar zimmî olup köle değildirler. Bu rivayetle ilgili olarak Süleyman b. Yesar, el-Velîd b. Abdilmelik'in Sevad halkını ganimet olarak kabul etmek istediğini, kendisinin ise Hz. Ömer'in kararını hatırlattığını ve onun da bu kararından vazgeçtiğini belirtir. ${ }^{19} \mathrm{~Hz}$. Ömer'in bu kararında ganimet hukukunun ötesinde insanî boyutun öne çıktığı görülmektedir. ${ }^{20}$

Yine konu ile ilgili başka bir rivayette ise Hz. Ömer'in Cabiye'ye gelmesi ve orada araziyi savaşanlar arasında dağıtmak istemesi üzerine Muaz b. Cebel buna karşı çıkmış ve Hz. Ömer'e şöyle demiştir: "Eğer sen bu toprakları Müslümanlar arasında bölersen, hiç arzu etmediğimiz bir durum hâsıl olur. Çünkü bu takdirde savaşa katılmış gazilerin ellerinde birçok mal ve mülk toplanır ve bu tekelleşmeye kadar gidebilir. Bunlar öldükten sonra, bir nesil gelir. Onlar gayret ve fedakârlıklarıyla İslamiyet'i korurlar; fakat ihtiyaçlarını gidermek için bir şey bulamazlar. Sen bu konuda şimdiki insanlarla birlikte gelecek nesillerin durumunu da hesaba katarak adım at." Bunun üzerine $\mathrm{Hz}$. Ömer Muaz b. Cebel'in tavsiyesine uyarak toprağı savaşanlara taksim etmekten vazgeçti. ${ }^{21}$

Bütün bu rivayetler değerlendirildiğinde $\mathrm{Hz}$. Ömer ve onun görüşünü paylaşan sahabe; (1) Fethedilen topraklar ganimet hükmünde sayılarak savaşa katılanlar arasında dağıtııırsa gelecek nesillere bir şey kalmayacağı, (2)

\footnotetext{
${ }^{18}$ Ebû Yusuf, Kitabü'l-Harâc, s. 197; Fayda, Hz. Ömer Zamanında Gayr-ı Müslimler, s. 12-13.

${ }^{19}$ Belâzûrî, Fütûhü'l-büldân, s. 303.

${ }^{20}$ Fayda, Hz. Ömer Zamanında Gayr-ı Müslimler, s. 17.

${ }^{21}$ Şelebî, Ta'lî̈lül-Âhkâm, s. 56; Fayda, Hz. Ömer Zamanında Gayr-ı Müslimler, s. 14.
} 
Böyle bir dağıtım gerçekleşip de topraklar bölüştürülünce, suların taksimi ve kullanımı hususunda, Müslümanlar arasında fesat çıkabileceği, (3) Esirlerin ganimet olarak dağıtılması halinde; bunların Müslümanlar için faydalı olmaları söz konusu iken aksine sömürü aracına dönüşeceği, bu nedenle paylaştırılmamasının daha hayırlı olacağı, (4) Müslümanların arazi ile ilgili işleri (çiftçiliği) iyi bilmemeleri ve cihadla yükümlü olan Müslümanların böylesi işlerle uğraşmaması gerektiği, (5) İslam devletinin, kalelerinin ve sınırlarının korunabilmesi için askerlere dolayısıyla onların ihtiyaçlarını, maaşlarını karşılamak için paraya intiyaç duyulduğu, (6) Muaz b. Cebel'in dikkat çektiği gibi toprakların dağıtılması halinde ileride bunların tek elde toplanmasının sakıncalı olduğu gibi bazı endişelere ve haklı gerekçelere sahiplerdi.

Buna karşılık, savaşta fethedilen toprakların, fetih hareketlerine katılan savaşçılar arasında tıpkı diğer ganimetler gibi paylaştırılmasını isteyen sahabiler ise (1) Askerlerin elde ettikleri ganimetlerin taksim edilişi gibi toprakların da dağıtılması gerektiğini, (2) Toprağın ganimet ve feyden farklı olmadığını, (3) Savaşa bizzat katılan, yani kendi kılıç güçleriyle kazanılan ganimetlerden olan bu toprakları, bu savaşlarda hazır bulunmayanlara veya onların çocuklarına ve sonraki nesillere bırakmanın doğru olmadığını, (4) Hz. Peygamber'in Hayber arazisini taksim ettiği gibi Irak, Sevad topraklarının dağıtılması gerektiğini savunmuşlar ve bu konularda kendilerinin haklı olduklarını belirtmişlerdir. ${ }^{22}$

Hz. Ömer konuyla ilgili görüşüne "[Ey müminler!] Onların mallarından Allah'ın, savaşılmaksızın peygamberine kazandırdığı mallar için siz, at ya da deve koşturmuş değilsiniz. Fakat Allah, peygamberlerini, dilediği kimselerin üzerine salıp onlara üstün kılar. Allah'ın her şeye hakkıyla gücü yeter. Allah'ın, (fethedilen) memleketlerin ahalisinden savaşılmaksızın peygamberine kazandırdığı mallar; Allah'a, peygambere, onun yakınlarına, yetimlere, yoksullara ve yolda kalmışlara aittir. O mallar, içinizden yalnız zenginler arasında dolaşan bir servet (ve güç) hâline gelmesin diye (Allah böyle hükmetmiştir). Peygamber size ne verdiyse onu alın, neyi de size yasak ettiyse

${ }^{22}$ Fayda, Hz. Ömer Zamanında Gayr-ı Müslimler, s. 15-16. 
ondan vazgeçin. Allah'a karşı gelmekten sakının. Şüphesiz, Allah'ın azabı çetindir. Allah'ın bahşettiği bu ganimetlerin bir kısmı, yurtlarından ve mallarından edilmiş olan, Allah'ın lütfunu ve rızasını arayan, Allah'ın dinine ve peygamberine yardım eden fakir muhacirleredir ki onlar davasına sadık olanlardır. Muhacirlerden önce bu yöreyi (Medine) yurt edinmiş ve [gönüllerine] imanı yerleştirmiş olanlar [Ensar], kendilerine hicret edip gelenleri severler; onlara (muhacirlere) verilenlere karşı içlerinde rahatsızlık hissetmezler, yoksulluk içinde bulunsalar dahi onları kendilerine tercih ederler. İşte bu şekilde nefsinin açgözlülüğünden korunmuş kimseler, mutluluğa erişeceklerdir. Onlardan sonra gelenler, "Ey Rabbimiz! Bizi ve bizden önce inanmış olan kardeşlerimizi bağışla ve imana ermiş olanlardan hiçbirine karşı kalplerimizde kin duygusuna yer bırakma. Ey Rabbimiz! Sen şefkatlisin, merhametlisin, diye dua ederler." mealindeki Haşr sûresinin 6-10. Ayetlerini delil göstermiştir. Bu içtihadı isabetli görmeyen taraf ise "Eğer Allah'a ve hakkın batıldan ayrıldığı, iki topluluğun savaşta karşı karşıya geldiği gün [Bedir'de] kulumuza [Hz. Muhammed] inzal ettiğimiz mesaja inanıyorsanız, bilesiniz ki, [savaşta] ganimet olarak ele geçirdiğinizin beşte biri Allah ve onun elçisine, yakın akrabaya, yetimlere, ihtiyaç içinde olanlara ve yolda kalmışlara aittir. Allah her şeye güç yetirendir." malindeki 8. Enfal 41. ayet ile Hz. Peygamber'in ele geçen ganimetlerle beraber Hayber arazisinin çoğunu taksim etmesini delil göstermişlerdir.

Ebû Yûsuf da Hz. Ömer'in söz konusu uygulamasını şu şekilde değerlendirir: “Hz. Ömer'in fethedilen toprakları taksim etmemesi, Allah'ın ona lütfettiği bir başarıdır. Bundan hasıl olan maslahat ise Müslümanlara aittir. Yine onun, fethedilen topraklardan vergi alması ve toplanan vergileri Müslümanlar arasında dağıtması, kamuya ait bir faydadır. Zira bu toprakların gelirleri, maaş ve diğer intiyaçlarda kullanılmak üzere halka vakfedilmiş olmasaydı, kaleler/sınırlar korunamaz, ordular savaş için hazır olamazdı. İhtiyaçları karşılanan ordular mevcut olmasaydı, inkarcıların İslam ülkelerine tekrar 
dönmelerine engel olunamazdı. Hayır ve faydanın nerede olduğunu Allah daha iyi bilir". ${ }^{23}$

Bütün bu görüşler ve rivayetler değerlendirildiğinde Hz. Ömer'in ganimet ve fey taksimi konusunda çok önemli bir uygulamayı başlattığı görülür. Onun ganimet taksimindeki bu uygulaması her ne kadar 8. Enfal 41. ayetteki hükme aykırı olsa da Kuran'ın temel maksatlarına uygun düşmektedir. Diğer bir deyişle onun bu konuyla ilgili uygulaması nassları hükümsüz kılmak değil, diğer naslarla istidlal ederek kamu yararının gereğini yapmaktır. Esasen daha önce Hz. Peygamber'in ganimet olarak alınan arazileri Müslümanlar arasında bölüştürmesi, o şartlarda bunu gerekli kılan ve o zamana bağlı "maslahat" düşüncesinin gereğiydi. Özellikle Mekke'den yurtlarını, mal ve mülklerini bırakarak hicret eden (muhacir) sahabeye bu konuda pay vermesi, maslahatı gözetmesi neticesinde olmuştur. Hz. Ömer dönemine gelindiğinde ise maslahat bu gibi arazilerin paylaştırılmamasını ve harac karşılığında esas sahiplerinde bırakılmasını mucip kılıyordu. Onun bu yönde maslahatı kullanması için bazı gerekçeleri vardır. Hz. Ömer'e göre eğer bu topraklar savaşanlar arasında dağıtılsaydı toprak ağaları ortaya çıkacak, topraklar üzerindeki ahalinin kölelik statüsü o an için başlayıp nesiller boyu devam edecek, bu paylaştırma neticesinde hisse sahibi olan kimselerden sonra gelenlere alacak bir şey kalmayacaktı. Kısacası sosyal adalet, ekonomik dengeler ve ileriki yıllarda güvenliğin temini açısından şiddetli bir sıkıntı ortaya çıkacaktı. ${ }^{24}$

Şu da gözden uzak tutulmamalıdır ki eğer Hz. Peygamber Hayber'in taksiminde toprakların bütününü dağıtmayıp bir kısmını kamu yararına dönük harcamalar için sürekli gelir sağlayacak şekilde işleyicilerin elinde vergi karşılığı bırakmış olsaydı, Hz. Ömer bunu delil göstererek kendisinin de $\mathrm{Hz}$. Peygamberin gözettiği bu maslahatı Sevad arazisinde bütünüyle gözetmek istediğini belirterek kendine muhalefet edenleri daha kolay ikna edebilirdi. ${ }^{25}$

\footnotetext{
${ }^{23}$ Ebû Yûsuf, Kitabü'l-Harâc, s. 29.

${ }^{24}$ Köse, Saffet, "Hz. Ömer'in Bazı Uygulamaları Bağlamında Ahkâmın Değişmesi Tartışmalarına Bir Bakış", İslam Hukuku Araştırmaları Dergisi, Konya 2016, sayı 7, s. 43.

${ }^{25}$ Şelebî, Ta'lîül-Âhkâm, s. 53.
} 


\section{Hz. Ömer'in Sevad Arazisi ile İlgili Tasarrufunun Fıkhî Tezahürleri}

Zahiren Kur'an'a aykırı olarak gözüken bu uygulamada önemli olan diğer bir nokta ise, devlet başkanlığı faktörüdür. Çünkü Hanefi fakihlere göre böyle bir konuda karar verme yetkisi devlet başkanına aittir. Zira Hz. Peygamber de devlet başkanı sıfatıyla konuya dair ayete uygun olarak bu yetkiyle belirli tasarruflarda bulunmuştur. Ancak şu da bir gerçektir ki Kur'an'da devlet başkanının böyle bir yetkisinin bulunduğundan pek de söz edilmemiştir. Diğer taraftan konuyla ilgili klasik İslam hukuku âlimleri Hz. Ömer'in bu uygulamasını salt ganimet ve toprak hukuku bağlamında ele almış, dolayısıyla konunun askeri, dini ve daha da önemlisi insani boyutunu inmal etmişlerdir. Oysa bu konu sadece toprak mülkiyeti ve ganimet hukuku çerçevesinde incelenemeyecek kadar önemli bir konudur. Çünkü Hz. Ömer'in topraklar ganimet olarak dağıtıldığı takdirde her Müslümana üç esir çiftçi düşeceği ve bu insanların devamlı olarak sömürüleceği, ancak buna asla müsaade edilemeyeceği gibi görüşleri konuya toprak hukukunun da ötesinde çok daha anlamlı boyutlar katmaktadır. ${ }^{26}$

Illk dönem Hanefi fakihlerinden Cessâs'a göre Hz. Ömer'in bu tasarrufu hem fey hem de ganimet hükümlerini düzenleyen ayetlerle birlikte ele alınmalıdır. Buna göre savaşla fethedilen yerlerde arazi dışında ele geçirilen mallarda ganimet ahkamı, arazilerdeyse fey hükümleri geçerli olup devlet başkanı duruma göre karar verir. İsterse ganimet hükümlerini uygular ve beşte biri çıktıktan sonra savaşanlara dağıtır. İsterse de fey hükümleri çerçevesinde arazileri sahiplerinde bırakır ve haraca bağlar. $\mathrm{Bu}$ ayetlerde bizzat $\mathrm{Hz}$. Peygamber'in isminin zikredilmiş olması, onun uygun gördüğü şekilde tasarrufta bulunma yetkisinin sadece kendisine ait olduğunu göstermektedir. Irak toprakları konusunda ise $\mathrm{Hz}$. Ömer, "Söz konusu ganimetler, içinizden yalnız zengin olanlar arasında dolaşıp duran bir servete dönüşmesin diye (Allah böyle hükmetmişsir.)" mealindeki ayetten hareketle toprakları dağıtması durumunda bunların sadece zenginler arasında dönüp dolaşan bir güç/servet olacağını kavramış ve Haşr sûresi 10. ayette geçen "onlardan sonra gelenler"

\footnotetext{
${ }^{26}$ Fayda, Hz. Ömer Zamanında Gayr-ı Müslimler, s. 17.
} 
ifadesinin kendilerine hak tanıdığı sonrakilere de bir şey kalmayacağını düşünmüştür. Bunun üzerine toprakları haraca bağlayarak eski sahiplerinin ellerinde bırakmıştır. Sahabe de onun bu konudaki uygulamasını desteklemiştir. ${ }^{27}$

Cessâs'ın bu görüşüne Şelebî şu eleştirileri yöneltmektedir: Cessâs'ın görüşü mevcut vakıayı doğrulamıyor. Çünkü Haşr sûresinin 6-7. Ayetleriyle ihticac olunamaz. Bilakis bu ayetler Hz. Ömer'in görüşünün isabetli olduğunu doğrudan açıklamaktadır. Çünkü fey'in Müslümanların maslahatı doğrultusunda tasarruf edileceği belirtilmektedir. Hz. Ömer'in uzun tartışmaları sona erdiren ve kendisinin meselenin delilini buldum dediği ayetle (Haşr 10. Ayet) ilişkilendirilmesinde aslında bir müşkil söz konusu ki buna bugüne kadar temas edilmemiştir. Zira ayetin siyakından bu mana çıkmadığı gibi Kur'ân'ın belâğatına da uymayan bir zorlama yorum söz konusudur. Aynı şekilde ayetin nüzul sebebi de buna imkân vermemektedir. Çünkü Hz. Peygamber savaş yapılmadan Nâdir oğullarından ele geçirilen malları muhacirlere taksim etmek istediğinde (o zaman muhacirlerin elinde hiçbir mal yoktu) ensardan bazıları bunlarda, ganimet mallarında olduğu gibi kendilerinin de haklarının olduğunu sanarak itirazda bulundular. Bunun üzerine $\mathrm{Hz}$. Allah onların bu durumunu kınayarak şöyle buyurdu: “[Ey müminler!] Onların mallarından Allah'ın, savaşılmaksızın peygamberine kazandırdığı mallar için siz, at ya da deve koşturmuş değilsiniz. Fakat Allah, peygamberlerini, dilediği kimselerin üzerine salıp onlara üstün kılar. Allah'ın her şeye hakkıyla gücü yeter.”. Hz. Peygamberin de "Bu muhacir kardeşleriniz mallarını ve çocuklarını terk ederek size geldiler." demesi üzerine Ensar, "mallarımızı onlara paylaştır" dediler. Hz. Peygamber ise bunun yeterli olmayacağını, zira onların tarımı, çiftçiliği bilmediklerini, onlara ekip dikmede kendilerinin yardımcı olmasını ve ürünün de paylaşılmasını öğütledi. Bunun üzerine konuyla ilgili bu ayetler onların savaşarak emeği geçmemesi nedeniyle söz konusu mallarda haklarının olmadığını açıklayarak tartışmaya son nokta koymuştur. Müfessirlerin

\footnotetext{
${ }^{27}$ Cessâs, Ebû Bekr Ahmed b. Alî Râzî, Ahkâmu'l-Kur'ân, Dâru İhyâi' Türasi'l-Arabî, Beyrut 1992, V, 319. Ayrıca bkz. Cessâs, Ebû Bekr Ahmed b. Alî Râzî, Şerhu't-Tahâvî, Dâru'l-beşâ'iri'l-İslâmiye, Beyrut 2010, IV, 235-237.
} 
bildirdiğine göre Ensar'dan birinin madem bunda bizim hakkımız yoksa nasıl pay edilecek sorusuna da cevap meyanında paylaşımı açıklayan "Allah'ın, (fethedilen) memleketlerin ahalisinden savaşılmaksızın peygamberine kazandırdığı mallar; Allah'a, peygambere, onun yakınlarına, yetimlere, yoksullara ve yolda kalmışlara aittir." Mealindeki Haşr sûresinin 7. Ayeti "Ey Ensar sizin zenginleriniz arasında dönüp dolaşan bir devlet olmasın" diyerek bu paylaşımın illetini de açıklamıştır. Çünkü o zaman muhacirlerin arasında zengin yoktu. Ayetin sonunda "Allah rasûlü size neyi verdiyse alın, neden yasakladıysa geri durun" denilerek onun emrine imtisali emretmekte, muhalefet etmeyi de yasaklamakta ve şiddetle cezalandırılacağını belirtmektedir. Daha sonra sadece muhacirlerin bu mallarda pay sahibi olduğu belirtilirken onların mallarından ve yurtlarından edildiği vurgulanmış ve diğer hak sahipleri de "onun akrabalarına, yetimlere ve miskinlere... aittir" denilerek zikredilmiştir. Daha sonra Medine'yi yurt edinen ensar ve ilk muhacirlerden sonra gelen Müslümanlar ise methedilmiş, ancak bunlara pay verileceği belirtilmemiştir. Ayetlerin bu şekilde anlaşılması, hem siyak-sibak itibariyle birbirini desteklemekte hem de sebeb-i nüzulüyle bütünlük arz etmektedir. Dolayısıyla mana da açık bir şekilde ortaya çıkmaktadır.

Netice itibariyle gelecek nesilleri pay sahibi grup içerisinde zikretmek zorlama bir yorum olup bu da bir kısım hükümlerin maslahata tabi olduğu görüşünden kaçınmak için başvurulan bir yoldur. Diğer taraftan Hz. Ömer'in inticac ettiği sonraki nesillerin de fey'de hakkının olduğuna dair rivayeti Muhammed b. İshak nakletmiştir. Şelebî'ye göre bu kimse hadis alimleri tarafından tedlis yapmakla cerh edildiği için onun bu rivayetiyle inticac etmek de isabetli değildir. ${ }^{28}$ Bununla birlikte rivayetin sahih olduğunu farz etsek bile

\footnotetext{
${ }^{28}$ Şelebî, Ta'lîül'-Âhkâm, s. 53-55. Buna rağmen Ebü'l-Hasen el-İclî (ö. 261/875) Muhammed b. İshak'ın sika bir ravi olduğunu zikretmiştir. Bkz. İclî, Ahmed b. Abdillah, Ma'rifetü’s-sikât, thk. Abdülalîm Abdülazîm el-Bestevî, I-II, Mektebetü'd-Dâr, Medine 1985, II, 232. Öte yandan pek çok muhaddis onun hakkında -Şelebî̀nni de dediği gibi- cerh ifadeleri kullanmıştır. Örneğin Nesâî (ö. 303/915) onun kavi olmadığını söylemiştir. Bkz. Nesâî, Ebû Abdirrahmân Ahmed b. Şuayb b. Alî, ed-Duafâ ve'l-Metrûkîn, thk. Bûrân ed-Dannâvî - Kemal Yusuf el-Hût, Müessesetü'I-Kütübi'sSekâfiyye, Beyrut 1985, s. 211. Mizzînin (ö. 742/1341) kaydettiğine göre tedlîs yapan ravilerden sayılmaktadır. Bkz. Mizzî, Ebü'l-Haccâc Yûsuf b. Abdirrahmân, Tehzîbü'l-Kemâl, thk. Beşşâr Avvâd Ma'rûf, I-XXXV, Müessesetü'r-Risâle, Beyrut 1983-1992, XXIV, 410. İbnü'l-Irâkî (ö. 826/1423) ise onun çokça tedlîs yapan zayıf ravilerden biri olduğunu zikretmiştir. Bkz. İbnü'I-Irâkî, Ebû Zür’a
} 
$\mathrm{Hz}$. Ömer'in ayette geçen zenginler arasında dönüp dolaşan bir servete dönüşmesi ve fakirlerin bundan mahrum kalması şeklindeki ta'lîli kendi görüşüne delil gösterdiğini kabul etmek daha isabetli olurdu. Nitekim bu yaklaşım Hz. Ömer'in "Bu benim görüşümdür (reyimdir)." şeklindeki sözüyle de çelişmemektedir. Diğer taraftan devamında "Eğer böyle olmasaydı paylaştıırdım" demesi de mevcut malların savaş yoluyla elde edilen ganimet malları kapsamında olduğunu göstermektedir.

Savaş sonucu elde edilen menkul malların (ganimetler) hükmü, Enfal suresinde geçmiş; savaş sonucu elde edilen araziler, gelirler, gayrimenkuller, haraç ve cizyeler olmak üzere fey kabul edilmiştir. Hak sahipleri Allah için, peygamber, onun yakınları (Ehl-i Beyt), yetimler, yoksullar ve yolda kalmışlar olarak belirlenmiştir. Haşr suresi 7. Ayette, "Allah'ın (fethedilen) memleketlerin ahalisinden savaşılmaksızın peygamberine kazandırdığı mallar; Allah'a, peygambere, onun yakınlarına, yetimlere, yoksullara ve yolda kalmışlara aittir. O mallar içinizden yalnız zenginler arasında dolaşan bir servet (ve güç) haline gelmesin diye Allah (c.c) böyle hükmetmiştir. Peygamber size ne verdiyse onu alın, neyi de yasakladıysa ondan vazgeçin. Allah'a karşı gelmekten sakının, şüphesiz Allah'ın azabı çetindir." buyrulmaktadır. 6. ayette, savaş olmaksızın sadece $\mathrm{Hz}$. Peygamber'e mahsus kılınan mallardan bahsedilir. 7. ayet ise savaş sonucu ele geçen mallarla (gayr-ı menkuller) ilgilidir. Nesefî̀ye göre 7 . ayetin başında atıf vav'ı olmadığından, 6. ayeti açıklayan bir ayet konumundadır. Yani Allah'ın, ona (Peygamberine) verdiği fey'i ne yapacağını açıklamaktadır. Bu payların beşe taksim edileceğini belirtmektedir. Kısaca 7. ayet, savaş yoluyla herhangi bir yerde alınan ganimetlerin sarf edileceği beş yeri açıklamaktadır. ${ }^{29}$ Allah'ın Rasulüne vermiş olduğu fey'den 8 . ve 9. ayetler

\footnotetext{
Ahmed b. Abdirrahîm, Kitâbü'l-Müdellisîn, thk. Rif'at Fevzî Abdülmüttalib-Nâfiz Hüseyin Hammâd, Dâru'l-Vefâ, Mensure 1995, s. 81. Ayrıca bkz. Sıbt İbnü'l-Acemî, Ebü'l-Vefâ Ibrahim b. Muhammed, et-Tebyîn li-esmâi'l-müdellisîn, thk. Yahya Şefîk Hasan, Dâru'l-Kütübi'I-IImiyye, Beyrut 1986, s. 47. Nitekim İbn Hacer (ö. 852/1449) de bunu teyit etmiştir. Bkz. İbn Hacer, Ebü'l-Fazl Ahmed b. Ali, Tabakâtü'l-müdellisîn, thk. Âsım b. Abdillah el-Kureyvitî, Mektebetü'l-Menâr, Ürdün ts., s. 14. Nihayet Süyûtînin (ö. 911/1505) ifadeleri de bu yöndedir. Bkz. Süyûtî, Ebü’l-Fazl Abdurrahman b. Kemâleddîn, Kitâbü Esmâi'l-müdellisîn, thk. Mahmûd Muhammed Mahmûd Hasan Nessâr, Dâru'lCîl, Beyrut 1992, s. 81.

${ }^{29}$ Nesefi, Celil b. Abdullah b. Ahmed b. Mahmud, Tefsiru'n-Nesefi, Dar'ul Marife, Beyrut 2000, s. 1224.
} 
muhacir ve ensâra da ele geçen mallardan pay verilmesi gerektiği, 10. ayette de sonraki Müslümanlar yani bütün ümmetin buna dahil olduğu ifade edilmiştir.

Fey', haraç, cizye, ticari mal vergisi, öşür ve ganimeti içine almakla birlikte cumhur ulemaya göre ganimet de fey'in dışındadır.

İmam Malik'e göre 7. ayet Ben-i Kureyza hakkındadır. ${ }^{30}$ Manası enfâl hükümlerine döner ve burada nesih de söz konusu olur.

Bu ayetlerden anlaşılan hüküm ve gayeler;

1- Allah (c.c) Ben-i Nadir mallarını 6. Ayette Hz. Peygambere has kılmıştır.

2- Ben-i Kureyza ve Ben-i Nadir mallarının 4/5'ü savaşanlar içindir. (7.ayet).

Bazı âlimler buradaki kişilerin enfal suresiyle neshedildiğini söylemektedir. İmam-ı Şafii'ye göre 6. ve 7. ayetlerin manası ve hükmü birdir; savaşmadan da olsa elde edilen mallar beşe ayrılır. Bu beş payın dördü $\mathrm{Hz}$. Peygamber'e aittir. 1/5'i de yine 5'e ayrılır. Bunun da 1/5'i Hz. Peygamber'e, akrabalarına (Ehl-i Beyt) zekâttan men edildikleri için fey'den onlara hak ayrılmıştır. Bunun dışında geri kalan paylar, yetimler, miskinler ve Allah yolunda olanlara dağıtılır. Hz. Peygamber zamanında bu şekilde pay ediliyordu. ${ }^{31}$

Hz. Peygamber'in vefatından sonra, Peygamber'e olan pay mücâhidlere ayrıldı. İmam-ı Şafii'ye göre, Müslümanların maslahatını gözeterek, Müslüman toplumun ihtiyacı olan eksikleri gidermek için öncesinde Hz. Peygamber'e ayrıımış olan pay buralara harcanır. Bu da bir bakıma gâî bir yorumdur. ${ }^{32}$

3- Bu bağlamda idareci ve valilerin tasarrufunda olan mallar üç kısma ayrılır;

I- Sadaka, zekat vb.

II- Ganimetler (savaş yoluyla elde edilen mallar)

III- Fey' (savaşsız elde edilen mallar) : cizye, haraç, öşür.

\footnotetext{
${ }^{30}$ Kurtubî, Ebû Abdillâh Muhammed, el-Cami'li Ahkami'l-Kur'an, Daru İbn Hazm, Beyrut 2004, II, 3029 .

${ }^{31}$ Kurtubî, el-Cami'li Ahkami'l-Kur'an II, 3028.

32 Kurtubî, el-Cami'li Ahkami'l-Kur’an, II, 3028-3029.
} 
Irak toprakları fethedildiği zaman, yaygın kanaate göre Hz. Ömer de bu anlayışa sahip bulunuyordu, Taberî'nin tercihi de bu yöndedir. Buna karşılık İmam Şafiî ile onun görüşünü benimseyenler bu iki ayeti birlikte değerlendirip 7. Ayeti önceki ayetin açıklaması olarak kabul ederler; onlar burada, sadece savaş yoluyla elde edilmeyen malların ve hükmünün söz konusu olduğu kanaatindedirler. ${ }^{33}$

Bu anlayışın en önemli pratik sonucu, savaş yoluyla elde edilen arazilerin de ganimet hükmünde sayılması ve 4/5'ünün savaşa katılanlar arasında dağıtılmasıdır. Öte yandan yine bu anlayışa göre barış yoluyla elde edilen mallar (fey'), ganimette olduğu gibi 5'e bölünüp ganimetin 1/5'inin dağıtıldığı zümreye dağıtılır, kalan $4 / 5$ yalnız $\mathrm{Hz}$. Peygamber'in hakkı olup $\mathrm{O}$, bunu Allah'ın kendisine gösterdiği yerlere harcar. Nitekim Hz. Ömer döneminde Irak topraklarının fethedilmesi üzerine Sevâd (Irak) arazisinin hangi statüye tabii tutulacağına ilişkin olarak sahabe arasında cereyan eden tartışmalar ve bunun ardından ortaya çıkan uygulama örneği hukuk doktrinlerinin bu konudaki tercihlerini büyük ölçüde etkilemiştir. Sevâd topraklarının fethedilmesini takiben gaziler, başkumandan Sa'd b. Ebû Vakkâs'a başvurup bu toprakların da diğer ganimet malları gibi kendilerine dağıtılmasını istemişler, o da bu talebi halife Hz. Ömer'e iletmiştir. Hz. Ömer, konuyu sahabe ile geniş biçimde tartıştıktan sonra menkul malların (ganimet statüsünde olmak üzere) Müslüman askerler arasında dağıtılmasına, arazi ve akarsuların ise -Haşr suresinin 7-10. Ayetlerine dayanarak- Müslümanların yararına vakıf (Fey' Mevkufe) olmak üzere sahiplerinin elinde bırakılmasına ve bunlardan elde edilecek haraç vergisinin Müslümanların atiyyelerine dâhil edilmesine (devlet hazinesine kaydedilmesine) karar vermiş ve bu yönde uygulama yapması için Sa'd b. Ebû Vakkas'a yazılı talimat göndermiştir. ${ }^{34} \mathrm{Bu}$ uygulamayı diğer deliller dışında değerlendiren hukuk doktrinleri, birbirinden farklı sonuçlara ulaşmışlardır:

\footnotetext{
33 Taberî, Ebû Ca'fer Muhammed b. Cerîr, Tefsîru't-Taberî, nşr. Ahmed Muhammed Şâkir, Mektebetü İbni Teymiyye, Kahire 1955-1969, XXIII, 276.

${ }^{34}$ Heyet, Kur'an Yolu Türkçe Meâl ve Tefsir, Diyanet İşleri Başkanlığı Yayınları, Ankara 2012, V, 289-290.
} 
-Hanefî mezhebine göre, savaş yoluyla elde edilen taşınmazlarda (gayrimenkul) devlet başkanının geniş bir takdir yetkisi bulunmaktadır: Devlet başkanı, duruma ve şartlara göre uygun görürse, Enfâl suresinin 41. Ayetinin hükümleri doğrultusunda (1/5'inin ayırdıktan sonra) toprağı gazilere taksim eder, bu durumda arazi öşür toprağı olur. Bunu uygun görmezse Hz. Ömer'in Sevâd toprakları hakkında yaptığı gibi yerli halkın elinde bırakır ve karşılığında onlara haraç vergisi yükler, bu takdirde arazi haraç toprağı olur.

-İmam Mâlik'e göre, savaş yoluyla ele geçirilen arazi, esas itibariyle dağıtılmaz; bu topraklar bütün Müslümanlar için ortak bir vakıftır, geliri ümmetin yararına sarf edilir. Ancak ümmetin menfaati taksimi gerektiriyorsa, devlet başkanı bu tür toprakların taksimine de karar verebilir.

-Şâfiîler'e göre ise, savaş yoluyla alınan topraklar ganimet hükümlerine tabii olup, devlet 1/5 hisse alır ve kalanı savaşanlara dağıtılır. Hz. Ömer'in uygulamasına gelince, İmam Şâfiî (Hz. Peygamber dönemindeki bir örnekten de yararlanarak) bunu savaşa katılanların rızası alınarak yapıldığını savunur.

-Hanbelîler'in bu konudaki yaklaşımı hakkında ise Şâfiî ve Mâlikîler'in görüşünü paylaşan iki farklı rivayet bulunmaktadır.

Uygulamada arazi daima Fey' hükümlerine tabii kılınarak ganimet hukuku dışında tutulmuş, dolayısıyla savaşanlara dağıtılması cihetine gidilmemiştir. 35

Hz. Ömer 7. ayetin "İçinizden sadece zenginler arasında dönüp dolaşan bir servet olmasın diye böyledir" şeklinde kısmını, toplum olarak elde edilen ve üretilen maddi değerlerin belirli kişilerin ellerinde tedahül edip kalmaması, sosyal adaletin sağlanması ve refahın geniş kitlelere yayılması gereğini vurgulayan bir ifade olarak anladığı için pek çok sahabe tarafından savunulan (şekil açısından da doğru gibi görünen) Irak arazisinin taksim edilmesi yönündeki görüşe katılmamış, özellikle ayetin bu kısmını delil göstererek ve taksim halinde ortaya çıkabilecek sorunlara dikkat çekerek onları bu arazilerin kamu gelirlerini arttıran bir kaynak haline getirilmesi hususunda ikna etmiştir.

\footnotetext{
${ }^{35}$ Ayrıntılı Bilgi İçin Bkz. Mustafa Fayda, 'Fey', DiA, XII, 511-513; Mehmet Erkal, 'Ganimet', DIA, XIII, 351-354; Kur'an Yolu, V, 288-293.
} 
Müzakerelerde Hz. Ömer'in, sosyal politikaya ilgili temel düşünceye atıf yapan ifadeler kullandığı da görülmektedir. ${ }^{36} \mathrm{~Hz}$. Ömer Irak topraklarının ganimet hükmünde sayılıp gaziler arası dağıtılmasına karşı ashab ile yaptığı tartışmalarda, özellikle 8-9. ayetlerden etkilenerek, hep 'sonraki nesiller' temasına vurgu yapmış, başlangıçta işin bu yönüne dikkat etmemiş olan sahabîler de çok geçmeden bu argüman ile ikna olmuşlardır. Bu da, toplum olarak övgüye layık, iyi Müslüman düzeyine erişebilmek için sahip olunan imkânları şuursuzca kullanmama, gelecek nesilleri ağır yük ve borç altına sokacak davranışlardan kaçınma sorumluluğunun bilincini taşımak gerektiğini (toplum maslahatı) ortaya koymaktadır. ${ }^{37}$

4- Âlimlere göre, kazanılan (fethedilen) topraklar da zenginleşip genişlemesi için kazanıldığı yerde pay edilir. Oradan da en yakında bulunan bölgeye aktarıı. Daha sonra sıkıntı çeken yerlerde bulunan kimselere $(\mathrm{Hz}$. Ömer'in kuraklık anındaki uygulamasında olduğu gibi) dağıtıır.

5- Eski cahiliye döneminde kabile reisi ganimetin 1/4ini alarak kalan kısmından da yine dilediğini alıyor idi. Bu hükümler (Fey' ayeti) ile Allah (c.c), zenginin daha zengin olmasını fakirin de daha fakir hale gelmesini engellemiştir.

6- "Hz. Peygamber ganimetten size ne verdiyse alın sizden neyi men ettiyse de onu istemeyin". Buradaki ayetler ganimet hakkında olsa da, $\mathrm{Hz}$. Peygamber'in bütün emir ve yasakları bu hükme dâhildir. ${ }^{38}$

7- Kim Allah'ın emrettiği şeye muhalefet ederse azap ile karşılaşır. Allah'ın emir ve yasaklarına riayet konusunda Allah'tan sakınılması emredilmiştir.

Gerek Kitap ve sünnet'te bulunan gerek icma ve ictihadlardan çıkan hükümler incelendiğinde, hikmet ile ta'lîin mümkün olduğu ve vuku bulduğu görülmektedir. Nitekim ictihad da bir bakıma bunu gerektirir.

\footnotetext{
${ }^{36}$ Kur'an Yolu, V, 290-291.

${ }^{37}$ Kur'an Yolu, V, 292.

${ }^{38}$ Kurtubi, El-Cami'li Ahkami'l-Kur'ân, II, 3030.
} 


\section{Değerlendirme ve Sonuç}

$\mathrm{Hz}$. Peygamber döneminde ganimetlerin dağıtımı ile ilgili uygulamaya zahiren ters düşüyor gibi görünmesine ve bazı sahabîlerin muhalefetine rağmen $\mathrm{Hz}$. Ömer, ganimetlerin taksiminde sahabenin büyük kısmının muvâfakatını almıştır. Bu uygulamada onun temel hareket noktası ümmetin maslahatı, varlığını sürdürmesi ve korumasıdır. Çünkü daha önce ganimetlerin dağıtılmasında olduğu gibi sevad arazisinin dağıtılması durumunda zannedildiği üzere beklenen faydanın gerçekleşmeyeceği aksine bu durumun zarara dönüşeceği, hatta ümmete büyük bir kötülük isabet edeceği düşüncesidir. ${ }^{39}$

Sahabe arasında günlerce (bazı rivayetlerde iki üç gün ${ }^{40}$ ) devam eden tartışmalara neden olan bu meselede ${ }^{41} \mathrm{~Hz}$. Ömer "Ben hüccet buldum" diyerek Haşr sûresinin 6-10. Ayetlerini okuduğunu, buna göre fey'in ayetlerde geçenlerin hepsi için ortak bir hak olduğunu, dolayısıyla gelecek nesilleri de düşünerek bunu taksim edemeyeceğini belirtir ve görüşünde Israr eder. ${ }^{42}$ Konuyu izah sadedinde önemli makul gerekçeler ileri sürer. Bu bağlamda Haşr sûresi 8,9 ve10 âyetleri birbiriyle irtibatlandırarak bir bütünlük içinde ele alarak cumhurdan farklı yorumlar. $\mathrm{O}$, bu ayetleri müstakil olarak değil ganimette hak sahiplerini açıklayan 6. Ayete atfederek bu ganimetlerden özellikle yurtlarından ve mallarından uzak kalmış Allah'ın rızasını isteyen muhacirlerin ve Ensarın hakkı olduğu gibi 8. ayette sözü edilen gelecek kuşakların da hakkının olduğu sonucuna ulaşır.

Nitekim ilgili ayette "Bunların arkasından gelenler şöyle derler: Rabbimiz! Bizi ve bizden önce gelip geçmiş imanlı kardeşlerimizi bağışla; kalplerimizde, iman edenlere karşı hiçbir kin bırakma! Rabbimiz! Şüphesiz ki sen çok şefkatli, çok merhametlisin!"43 buyurularak daha sonra gelecek nesillerin de bu

\footnotetext{
${ }^{39}$ Şelebî, Ta'lîlü'l-Âhkâm, s. 48-49.

40 Şelebî, , Ta'lîlü'l-Âhkâm, s. 50.

41 Serahsî, Ebû Bekr Muhammed b. Ahmed, el-Mebsût, Dâru'l-Ma'rife, Beyrut 1989, X, 15-16; İbn Rüşd, Ebü'l-Velîd Muhammed b. Ahmed b. Muhammed Kurtubî, Bidâyetü'l-Müctehid ve Nihayetü'lMuktesıd, Kahraman Yayınları, İstanbul, 1984; II, 401; Bardakoğlu, Ali, İslam Hukukunda Metodolojik Ihtilaflar ve Sonuçları (Ders Notları) Kayseri 1987, s. 9-10.

42 Fayda, Hz. Ömer Zamanında Gayr-ı Müslimler, s. 10.

${ }^{43}$ Haşr 59/10.
} 
ganimetlerde hakkı olduğuna işaret edilmektedir. Ancak kurulan bu ilginin çok güçlü olmadığını da söyleyebiliriz. Çünkü ayetlerin bütünlüğü ve insicamından bu mananın çıkması biraz güç gözüküyor. Bunun yerine onun doğrudan maslahatı gözettiği ciheti daha isabetli görünmektedir. Çünkü o, bir çok yerde bunun kendisinin re'yi olduğunu dillendirmektedir.

Hz. Ömer'in sadece bu uygulaması değil daha sonraki uygulamalarda da arazi daima fey' hükümlerine tabi kılınarak ganimet hukuku dışında tutulmuş, dolayısıyla savaşanlara dağıtılması cihetine gidilmemiştir. ${ }^{44}$

Aslında fey'in taksiminde hak sahiplerini açıklayan "Allah'ın, (fethedilen) ülkeler halkından Peygamberine verdiği ganimetler, Allah, Peygamber, yakınları, yetimler, yoksullar ve yolda kalmışlar içindir. Böylece o mallar, içinizden yalnız zenginler arasında dolaşan bir devlet olmasın..."45 meâlindeki ayet de Hz. Ömer'in bu uygulamasının isabetli olduğuna delâlet eder. Çünkü âyette söz konusu taksim gerekçelendirilirken bu elde edilen fey' (ganimetler)in cahiliyede olduğu gibi fakir ve güçsüzlerin yoksun bırakıldığı, zenginler, güçlüler ve idareciler arasında paylaştırılan ve onlar arasında dolaşan bir servete dönüşmemesine vurguda bulunulmuştur. Böylece servetin belirli bir kesimin elinde toplanarak diğerlerinin bundan mahrum kalmaması ve ümmetin bütününe yayılmasını hedeflenmiştir. ${ }^{46}$

Nitekim cahiliye döneminde elde edilen ganimetlerin en iyisini gücü elinde bulunduran kabile reisleri alır, geride kalan ve beğenilmeyen değersiz malları ise fakirlere bırakılırdı. Allah, zulüm ve haksızlığın cari olduğu, fakirlerin ezildiği bu sisteme son vererek, ihtiyaç odaklı, muhtaç ve fakirlerin de dikkate alındığı âdil bir paylaşımı tesis etmiştir. ${ }^{47}$ Neticede ayette "zenginler arasında dolaşan bir servet olmasın" denilmesi "cahiliye hükmüne" dönülmemesi noktasında bir uyarı teşkil edip bu da gâî açıdan fey yoluyla elde edilen servetin

\footnotetext{
${ }^{44}$ Ayrıntılı Bilgi İçin Bkz. Fayda, Mustafa, "Fey” , DiA, XII, 511-513; Erkal, Mehmet, 'Ganimet', DiA, XIII, 351-354.

${ }^{45}$ Haşr 59/7.

46 İbn Âşûr, et-Tahrîr ve't-Tenvîr, Müessesetü Târihi'l-Arabî, Beyrut 2000, XXVIII, 76; Şaban, Zekiyyüddin, İslam Hukuk İlminin Esasları, Ankara 2003, s. 159-160.

${ }^{47}$ Şelebî, Ta'lîül'-Âhkâm, s. 18; İbn Âşûr, et-Tahrîr ve't-Tenvîr, XXVIII, 76.
} 
adil bir şekilde paylaşımını hedeflemektedir. Hz. Ömer'in de Irak topraklarıyla ilgili tasarrufunda bu uyarıyı dikkate almış olduğu düşünülebilir.

Şâriin maksûdu olan gâyeler bilindikten sonra nasların bu maksada uygun bir şekilde gâi manalarının da dikkate alınarak yorumlanması mümkündür.

Hz. Ömer'in Irak topraklarıyla ilgili tasarrufunda bu gâi yorum başat rol oynamışıı. Zira onun, bu araziyi savaş gazileri arasında dağıtmayıp vergi karşılığında eski sahiplerinde bırakması, kamu yararını gözetmesinin yanında gelecek nesilleri düşünen uzun vadeli bir hikmete mebnidir. Aksi halde büyük bir kitlenin, köle statüsüne getirilmesi ve topraklarının da ganimet olarak dağıtılması söz konusu olurdu ki bu duruma düşürülen insanlar İslam'dan soğuyacak bunların çocukları da Müslümanlara düşmanlık besleyeceklerdi. Neticede $\mathrm{Hz}$. Ömer'in bu tasarrufu, daha sonraki uygulamalar için de ilham kaynağı olmuş, nitekim Osmanlı devletindeki mîrî arazi sisteminin oluşumuna model ${ }^{48}$ teşkil etmiştir.

\section{Kaynakça}

Bardakoğlu, Ali, İslam Hukukunda Metodolojik Ihtilaflar ve Sonuçları (Ders Notları) Kayseri 1987.

Belâzurî, Ahmed b.Yahya, Fütûhu'l-Büldân, (çev. M. Fayda) Siyer Yayınları, İstanbul 2013.

Buhârî, Muhammed b. İsmâil, Sahîhu'l-Buhârî, Dâru İbn Kesîr, Beyrut 1993.

Cessâs, Ebû Bekr Ahmed b. Alî Râzî, Ahkâmu'l-Kur'ân, Dâru Ihyâi' Türasi'l-Arabî, Beyrut 1992.

Cessâs, Ebû Bekr Ahmed b. Alî Râzî, Şerhu't-Tahâvî, Dâru'l-beşâ'iri'lİslâmiye, Beyrut 2010.

Cin, Halil, Mirî Arazi ve Bu Arazinin Özel Mülkiyete Dönüşümü, Selçuk Üniversitesi Yayınları, Konya 1987.

Demirci, Mustafa, "Sevâd" DIA, İstanbul 2009.

Ebû Yusuf, Kitabu'I-Harâc, Dâru'I-Marife, Beyrut, t,y.

Erkal, Mehmet, "Ganîmet" DiA, İstanbul 1996.

Fayda, Mustafa, "Fey” , DIA, İstanbul 1995.

\footnotetext{
${ }^{48}$ Bkz. Cin, Halil, Mirî Arazi ve Bu Arazinin Özel Mülkiyete Dönüşümü, Selçuk Üniversitesi Yayınları, Konya 1987, s. 46-47.
} 
Fayda, Mustafa, Hz. Ömer Zamanında Gayr-ı Müslimler, Marmara Üniversitesi Yayınları, İstanbul 1989.

Heyet, Kur'an Yolu Türkçe Meâl ve Tefsir, Diyanet İşleri Başkanlığı Yayınları, Ankara 2012.

İbn Âşûr, et-Tahrîr ve't-Tenvîr, Müessesetü Târihi'l-Arabî, Beyrut 2000.

İbn Âşûr, Muhammed Tâhir, İslam Hukuk Felsefesi, (çev. Mehmet Erdoğan; Vecdi Akyüz) Rağbet Yayınları, İstanbul 2006.

İbn Hacer, Ebü'l-Fazl Ahmed b. Ali, Tabakâtü'l-müdellisîn, thk. Âsım b. Abdillah el-Kureyvitî, Mektebetü'l-Menâr, Ürdün ts.

İbn Rüşd, Ebü'l-Velîd Muhammed b. Ahmed b. Muhammed Kurtubî, Bidâyetü'l-Müctehid ve Nihayetü'l-Muktesıd, Kahraman Yayınları, İstanbul, 1984.

İbnü'l-Irâkî, Ebû Zür'a Ahmed b. Abdirrahîm, Kitâbü'l-Müdellisîn, thk. RIf'at Fevzî Abdülmüttalib-Nâfiz Hüseyin Hammâd, Dâru'l-Vefâ, Mensure 1995.

İclî, Ahmed b. Abdillah, Ma'rifetü's-sikât, thk. Abdülalîm Abdülazîm elBestevî, I-II, Mektebetü'd-Dâr, Medine 1985.

Köse, Saffet, “Hz. Ömer'in Bazı Uygulamaları Bağlamında Ahkâmın Değişmesi Tartışmalarına Bir Bakış”, İslam Hukuku Araştırmaları Dergisi, Konya 2016.

Kurtubî, Ebû Abdillâh Muhammed, el-Cami'li Ahkami'l-Kur'an, Daru İbn Hazm, Beyrut 2004.

Mizzî, Ebü'l-Haccâc Yûsuf b. Abdirrahmân, Tehzîbü'l-Kemâl, thk. Beşşâr Avvâd Ma'rûf, I-XXXV, Müessesetü'r-Risâle, Beyrut 1983-1992.

Müslim, Müslim b. el-Haccâc, Sahîhu Müslim, Dâru İhyâi'l-Kütübi'lArabiyye, Kahire 1991.

Nesâî, Ebû Abdirrahmân Ahmed b. Şuayb b. Alî, ed-Duafâ ve'l-Metrûkîn, thk. Bûrân ed-Dannâvî - Kemal Yusuf el-Hût, Müessesetü'l-Kütübi's-Sekâfiyye, Beyrut 1985.

Nesefi, Celil b. Abdullah b. Ahmed b. Mahmud, Tefsiru'n-Nesefi, Dar'ul Marife, Beyrut 2000.

Serahsî, Ebû Bekr Muhammed b. Ahmed, el-Mebsût, Dâru'l-Ma'rife, Beyrut 1989.

Sıbt İbnü'l-Acemî, Ebü'l-Vefâ İbrahim b. Muhammed, et-Tebyîn liesmâi'l-müdellisîn, thk. Yahya Şefîk Hasan, Dâru'l-Kütübi'l-İlmiyye, Beyrut 1986.

Süyûtî, Ebü'l-Fazl Abdurrahman b. Kemâleddîn, Kitâbü Esmâi'lmüdellisîn, thk. Mahmûd Muhammed Mahmûd Hasan Nessâr, Dâru'l-Cîl, Beyrut 1992. 
Şaban, Zekiyyüddin, İslam Hukuk IIIminin Esasları, Ankara 2003.

Şâtıbî, Ebû İshak, el-Muvâfakât, Dâru'l-Fikr, y.y., t.y.

Şelebî, Muhammed Mustafa, Ta'lîlü'l-Âhkâm, Beyrut 1981.

Taberî, Ebû Ca'fer Muhammed b. Cerîr, Tefsîru't-Taberî, nşr. Ahmed Muhammed Şâkir, Mektebetü İbni Teymiyye, Kahire 1955-1969.

Tirmizî, Muhammed b. İsa, Sünen, Matba'ati Mustafa el-Bâbî, 19621977. 


\title{
A Review of the Practice of Caliph Umar for the Sawad Land from Teleological Interpretation/Maqasid
}

Citation / @- Aslan, N. (2018). A Review of The Practice of Caliph Umar for The Sawad Land from Teleological Interpretation/Maqasid, Cukurova University Journal of Faculty of Divinity, 18 (2), 691-717.

\begin{abstract}
As known, there are two main schools of interpretation in law: literal and teleological. Unfortunately, the scholars have almost never gone beyond the literal interpretation to address the issues of implication (delalet) modes under the related chapter and the qiyas subjects in the procedures of Islamic Jurisprudence (Usul al-fiqh), with some exceptions. The reason results in why wisdom (hikmah) and purpose, the essentials in the Islamic Nass, have been neglected.

In fact, the Almighty Allah do always have a specific purpose in establishing rules as He builds creation upon certain wisdom. In this context, the worldly and otherworldly goodness of His servants are considered with the provisions of Quran and Sunnah. According to this, in Islamic literature the five essentials that Islam aims to maintain, called the Purposes of Shariah (Maqasid al-Sharia), consist of the "universal goals", which is briefly defined as "the preservation of life, property, offspring, religion (Islam) and intellect". These principles, in one respect, constitute the general purpose of the Shariah-maker with provisions and in the other respect, involve the common interests of human beings. However, Allah has particular aims for any provision present in any Islamic Nass. It may actually be the specific purpose related to its delivery of that rule. Consequently the Nass of concern has to be interpreted in line with such a particular aim as well as the universal goals.

In consideration that the Nass are limited and yet the cases are unlimited, it is true that the literal interpretation will not meet the requirements. Therefore, for the new challenges facing the Muslims, it is likely to make a reasonable connection between the revelations and these new occurrences, by taking into consideration the purposes of the Shariah Maker, Allah.

Once the intent of the Shariah Maker has been recognized anyhow, the Nass may be interpreted in consistency with His purposes. In fact, several actions of his Holiness Caliph Umar are the best practices of this fact. His practice of Sawad land (or Iraqi territory) where the Islamic army conquered at that time is one of the most unique examples in teleological interpretation. The Iraqi lands had been gained through fights with swords by Muslims, and the Sawad land had to be allotted when considering the Ayah 41 Surah Anfal and the practice of the Prophet Mohammad, peace be upon him, regarding the apportionment of Khyber lands as well as the requirement of the apparent truth from the relevant Nass. Whereas, His Holiness Caliph Umar determined that the land properties be left to the current owners without re-allocation of this territory and instead, tributary taxes be collected on the real estates and the income gained from here be spent on public goods. His decision would contribute to a running debate among the Ashab Kiram. On the purpose of paying attention to the likeliness that several adverse outcomes will occur in short and long term if this usual practice remains, our aim in this study is to address and discuss the grounds of His Holiness Caliph Umar, who applied his own discretion to the ruling, in all respects. Furthermore, we will also deal with the reflections into Islamic Law of such a practice made by His Holiness Caliph Umar.
\end{abstract}

Keywords- Teleological interpretation, the Caliph Umar his Holiness, Wisdom (Hikmah), the Sawad land, War booty. 